\title{
Analisis Pandangan Gereja Terhadap Praktik Perbudakan Dalam Tradisi Suku Sumba
}

\author{
Jessica Tirza Felle, Armin Sukri Kana \\ Sekolah Tinggi Filsafat Theologia Jaffray Makassar \\ Email: jessicafelle19@gmail.com
}

\begin{abstract}
Every association in a community structure has customary norms passed down by the ancestors, both orally and in writing. Indonesia is one of the countries that inherits traditions from their ancestors, therefore Indonesia is known as a country that is rich in culture. One tradition that was passed down was the practice of slavery. This study aims to analyze the church's views on the practice of slavery and how the church overcomes the practice of slavery to the congregation and society. The method used in this research is a phenomenological research method with the following data collection techniques: First, literature study. Second, direct observation. Third, interviews with several people who are key people and who have influence in the area. Thus it can be concluded that so that the practice of slavery can be minimized in areas where this practice is implemented so that the church and the government can work together to deal with the main problem that causes this practice to persist.
\end{abstract}

Key Words: Church, Practice, Slavery, Culture, and Sumba.

\begin{abstract}
Abstrak
Setiap perkumpulan dalam tatanan masyarakat memiliki norma adat istiadat yang diwariskan oleh para leluhur, baik itu secara lisan maupun tulisan. Indonesia merupakan salah satu negara yang mewarisi tradisi-tradisi dari para leluhur maka dari itu Indonesia dikenal dengan negara yang kaya akan budaya. Salah satu tradisi yang diwariskan adalah praktik perbudakan. Penelitian ini bertujuan untuk menganalisis pandangan gereja mengenai praktik perbudakan dan bagaimana gereja mengatasi praktik perbudakan kepada jemaat dan masyarakat. Metode yang digunakan dalam penelitian ini metode penelitian fenomenologi dengan teknik pengumpulan data sebagai berikut: Pertama, studi kepustakaan. Kedua, observasi langsung. Ketiga, wawancara kepada beberapa orang yang menjadi orang kunci dan yang mempunyai pengaruh di daerah tersebut. Dengan demikian dapat disimpulkan bahwa agar praktik perbudakan bisa diminimalisirkan di daerah-daerah yang memberlakukan praktik ini agar gereja dan pemerintah bisa bekerja sama untuk menangani masalah utama yang menyebabkan praktik ini terus ada.
\end{abstract}

Kata-kata Kunci: Gereja, Praktik, Perbudakan, Budaya, dan Sumba.

\section{Pendahuluan}

Setiap perkumpulan dalam tatanan masyarakat memiliki norma adat istiadat yang diwariskan oleh para leluhur, baik itu secara lisan maupun tulisan. Indonesia merupakan salah satu negara yang mewarisi tradisi-tradisi dari para leluhur. Para ahli berpendapat bahwa tradisi merupakan warisan atau norma adat istiadat, kaidah-kaidah, dan harta-harta tetapi tradisi bukan suatu yang tidak bisa dirubah, justru tradisi merupakan perpaduan dengan 
beragam perbuatan manusia dan diangkat dalam keseluruhannya. ${ }^{1}$ Tradisi-tradisi selalu diwariskan kepada generasi ke generasi dengan harapan tradisi-tradisi tersebut terus dilestarikan. Tradisi juga berarti segala sesuatu yang disalurkan atau diwariskan dari masa lalu ke masa kini. Shil menegaskan bahwa: "manusia tak mampu hidup tanpa tradisi meski mereka sering merasa tak puas terhadap tradisi mereka". ${ }^{2}$ Hal ini berarti tradisi merupakan kebiasaan yang tidak terlepas dari suatu zaman, hal ini terjadi secara turun-temurun dan menjadi sebuah kebiasaan dalam bagian kehidupan masyarakat. Suatu praktik yang terjadi dalam suatu kelompok tidak terlepas dari sebuah tradisi yang secara sengaja dilakukan untuk melestarikan tradisi tersebut.

Indonesia merupakan negara yang memiliki keanekaragaman suku dan hal ini yang menjadikan Indonesia lebih dikenal dengan corak kebudayaannya, dikatakan di dalam salah satu media nasional "Republik Indonesia merupakan negara kepulauan terbesar di dunia yang terdiri dari 17.504 pulau"3 hal ini yang menjadikan Indonesia memiliki keanekaragaman budaya dan tradisi. Karena banyaknya budaya dan tradisi menjadikan Indonesia memiliki banyak sekali fenomena-fenomena dan hal ini menjadikan identitas Indonesia sebagai negara yang kaya akan budaya, tradisi, kepercayaan, dan kebiasaan yang diturunkan oleh para pendahulu-pendahulu. Banyaknya daerah-daerah di Indonesia menjadikan Indonesia kaya akan budaya dan tradisi, dan salah satu wilayah tersebut adalah, Sumba Timur. Sumba Timur merupakan salah satu kabupaten di kepulauan Nusa Tenggara Timur. Sumba merupakan salah satu daerah yang kaya akan budaya dan tradisi dan salah satu tradisi di tempat ini adalah praktik perbudakan.

Di Yunani dan Romawi perbudakan mempunyai nilai ekonomis dan hal itu masih ada hingga abad ke-10 M, biasanya mereka bekerja sebagai buruh pertambangan, pabrik, dan proyek pembangunan. Mereka juga bekerja di perkebunan, peternakan, dan juga menjadi pembantu dalam rumah-rumah. Biasanya budak laki-laki juga menjadi prajurit perang untuk mempertahankan negara atau kerajaan, sedangkan budak wanita menjadi penghibur di istana atau di muka umum. ${ }^{4}$ Praktik tersebut membuktikan bahwa stratifikasi sosial itu memang benar adanya dan perbudakan terjadi karena adanya golongan dalam setiap masyarakat.

Praktik perbudakan terjadi karena adanya startifikasi sosial dalam tatanan masyarakat dan akibat dari adanya stratifikasi sosial ialah terjadinya lapisan-lapisan, golongan-golongan dalam masyarakat yang mengakibatkan status sosial menjadi tampak nyata dari kasus tersebut. Strata sosial memang sudah ada sejak dahulu kala dan tampaknya masih terusmenerus terjadi hingga saat ini dan ini merupakan tradisi dalam setiap tatanan masyarakat.

\footnotetext{
${ }^{1}$ Putu Pertama Yasa, Ketut Sidang Partayasa, dan I Nyoman Linggih, “Tradisi 'Nyakan Diwang' Untuk Mempererat Tali Persaudaraan," http://jayapanguspress.penerbit.org/index.php/PN/article/view/341/331, (19 April 2020), 166.

${ }^{2}$ Edward Shils dan dkk, Elit Dalam Perspektif Sejarah (Jakarta: Lembaga Penelitian, Pendidikan dan Penerangan Ekonomi, 1981), 19.

3 “24 Rekor Dunia yang Dipegang Indonesia," diakses 21 Februari 2020, https://www.kompasiana.com/misdianto/54ff581aa333112b4a50ff8e/24-rekor-dunia-yang-dipegang-indonesia.

${ }^{4}$ Ahmad Sayuti Anshari Nasution, "Perbudakan dalam Hukum Islam," Jurnal Ilmu Syariah 15, no. 1 (Februari 2019): 96, doi:10.15408/ajis.v15i1.2852.
} 
Sistem lapisan dalam masyarakat, dalam sosiologi dikenal dengan social stratification. Kata stratification berasal dari stratum (jamaknya: strata, yang berarti lapisan). Patirim A. Sorokin, mengatakan stratifikasi sosial merupakan pembedaan penduduk atau masyarakat ke dalam kelas-kelas tinggi dan kelas-kelas lebih rendah. ${ }^{5}$

Pembedaan ini mengakibatkan terjadinya praktik perbudakan yang menandakan perbedaan dalam kehidupan status ekonomi dan sosial masyarakat dan hal ini biasanya ditandai dengan adanya tuan dan hamba atau adanya atasan dan bawahan, hal ini menunjukan perbedaan perekonomian dalam kehidupan bermasyarakat. Perbudakan bukanlah sesuatu yang baru bagi bangsa-bangsa disetiap sudut dunia, bukan hanya dikenali oleh bangsa yang ahli dalam pertanian dan yang pasti adalah perbudakan telah mempunyai dasar yang kuat sebelum pencatatan-pencatatan pertama daripada sejarah Mesopotamia dan Mesir. Pada abad pertengahan praktik perbudakan tetap berlangsung di Eropa, tetapi praktik tersebut mulai berkurang semenjak "sistim izin kerja pada tanah milik bangsawan" untuk sebagian besar digantikan dengan setengah kebebasan daripada petani yang terikat kontrak, di sisi lain ditemukannya "Dunia Baru" dan hal itu membangkitkan perdagangan budak belian yang mencakup seluruh dunia dan setelah diketahui bahwa orang-orang Negro dari Afrika dapat dipergunakan di perkebunan-perkebunan dengan iklim yang lebih panas mereka semakin menjadi-jadi pasalnya pada tahun 1619 orang-orang Negro yang pertama-tama dikirimkan ke Amerika Serikat dan setelah bertahun-tahun perbudakan menjadi "adat kebiasaan yang khas". 6

Menurut Ivan Weismann dakam tulisannya yang dimuat di Jurnal Jaffray menyatakan bahwa seperti sebagaimana teori perbudakan itu diketahui bahwa baik untuk seorang budak memiliki majikan begitu pula seorang majikan memiliki budak. Budak mempunyai nilai sebagai properti/kepemilikan. Apakah dari kekuasaan maupun institusi, apakah budak bukan miliknya sendiri dan dia adalah milik orang lain? Weismann juga menuliskan bahwa Aritoteles mengatakan hal serupa bahwa "budak bisa disebut sebagai kepemilikian orang lain yang juga adalah suatu kepemilikan." Hal ini menunjukan bahwa ada hubungan saling ketergantungan, yaitu menguntungkan satu sama lain. Weismann lebih jelas mengatakan budak akan nampak milik majikannya sejauh dia adalah suatu kepemilikan. ${ }^{7}$

Budak dalam pandangan politik hanya memiliki nilai ekonomis, mereka tidak mempunyai hak atas diri mereka sendiri, banyak hal yang direnggut dari mereka bukan harta, tetapi lebih kepada hak-hak mereka, mereka tidak dapat merasakan kebebasan HAM. Perlakuan yang diterima oleh para budak pada zaman jahiliah, yaitu: kebebasan, hak, kenyamanan, kesejahteraan, kehormatan itu semua dirampas dari pada mereka, penyiksaan diterima oleh mereka, dan juga mereka diperjualbelikan sebagai sebuah barang. Perlakuan

\footnotetext{
${ }^{5}$ Dorkas Jami dan David Samiyono, Maramba dan Ata: Hubungan raja dan hamba di Desa Patawang - Sumba Timur (Salatiga: Fakultas Teologi Universitas Kristen Satya Wacana Press, 2009), 10.

${ }^{6}$ A. G. Pringgodigdo, Ensiklopedi Umum (Yogyakarta: Kanisius, 1991), 838.

${ }^{7}$ Ivan Th. J Weismann, "Naturalisasi Perbudakan Sebagai Suatu Keadilan," Jurnal Jaffray. No. 1
} (2015): 34 . 
yang diterima oleh mereka pun masih ada sampai pada zaman modern. Jika diperhatikan hubungan antara majikan dan budak sampai saat ini masih akrab ditemui walaupun dalam bentuk tindakan yang berbeda dari zaman jahiliah. Ciri-ciri ${ }^{8}$ perlakuan budak pada masa modern ini, yaitu pertama, merampas kebebasan. Perlakuan majikan kepada buruh atau pembantu rumah tangga dengan mempekerjakan mereka secara paksa. Kedua, merampas hak. Perampasan hak buruh atau pembantu rumah tangga yang dilakukan oleh majikan sangat ramai ditemukan, keluhan dari para buruh banyak disuarakan seperti, tidak mendapat upah setelah bekerja bertahun-tahun, mempekerjakan buruh dengan gaji yang jauh di bawah standar. Semua itu merupakan modus perbudakan di zaman modern. Ketiga, merampas kenyamanan dan kesejahteraan. Perlakuan yang tidak manusiawi diterima oleh buruh atau pembantu rumah tangga, seperti tempat tinggal yang tidak layak, yang biasa ditemui adalah para buruh tinggal bersama ternak dan mendapatkan makanan sisa dari tuannya, ini adalah modus yang banyak terjadi dalam perbudakan zaman modern. Keempat, merampas kehormatan. Tindakan ini lebih dirasakan oleh perempuan, di mana mereka menjadi pelayan seks diberbagai tempat-tempat hiburan. Kelima, melakukan penyiksaan. Tindakan majikan kepada buruh atau pembantu rumah tangga dengan melakukan penganiayaan yang tidak sedikit berujung kepada kematian. Keenam, memperjualbelikan. Kegiatan jualbeli terhadap anak dan wanita yang sangat ramai ditemui, dan ini adalah modus pelengkap perbudakan di zaman modern ini.

Terlepas dari sifat perbudakan modern yang multifaset dan jarang diamati, kebanyakan orang percaya bahwa ada beberapa bentuk perbudakan yang cukup umum, ${ }^{9}$ yang pertama, perbudakan budak. Perbudakan budak adalah bentuk yang paling dekat dengan perbudakan lama. Seseorang ditangkap, lahir, atau dijual ke dalam perbudakan permanen, dan kepemilikan seringkali dinyatakan. Anak-anak yang lahir dari seorang budak biasanya juga diperlakukan sebagai milik dan dapat dijual oleh majikan orangtuanya. Kedua, perbudakan utang. Perbudakan utang adalah bentuk umum perbudakan dunia. Seseorang menjanjikan peminjaman uang, tetapi masa dan sifat lamanya peminjamannya tidak ditentukan, dan pekerjaan tidak mengurangi utang aslinya. Ketiga, perbudakan kontrak. Perbudakan kontrak menggambarkan bagaimana bentuk-bentuk perbudakan baru yang mana tersembunyi dalam kerangka kerja yaitu hubungan kerja modern dan bentuk perbudakan ini merupakan bentuk perbudakan yang paling cepat berkembang.

Perbudakan menjadi salah satu ikon yang terkenal di pulau dengan sematan yang diberikan, dan itu adalah sematan "tanah para hamba dan tuan". Sumba dikenal dengan kaya akan budaya dan tradisi hal tersebut menjadikan Sumba Timur cukup dikenal oleh kalangan masyarakat dan praktik-praktik tersebut masih bisa ditemui, dan salah satu tempat yang pernah menjadi objek penelitian lapangan, yaitu di desa Patawang, Sumba Timur yang

\footnotetext{
${ }^{8}$ Ahmad Sayuti Anshari Nasution, "Perbudakan dalam Hukum Islam,” Jurnal Ilmu Syariah 15. No. 1 (Februari 2019): 100-101, doi:10.15408/ajis.v15i1.2852.

${ }^{9}$ Kevin Bales, "Expendable People: Slavery in the Age of Globalization," Journal of International Affairs 53. No. 2, (2000): 463.
} 
dilakukan oleh seorang dekan dari Universitas Kristen Satya Wacana, alm. Bpk. David Samiyono bersama dengan rekannya melakukan penelitian mengenai hubungan maramba ata.

Samiyono dalam kesempatannya mewawancarai penduduk setempat dan menurutnya secara umum kebudayaan disetiap desa tidak memiliki perbedaan yang signifikan. Menurut Umbu Dати Halakudu mengatakan bahwa kelompok bangsawan tersebar ditujuh paraingu yang ada di desa Patawang. ${ }^{10}$ Salah satu dari ketujuh kampung itu dipercayai bahwa menjadi tempat pertama di mana para leluhur datang bersama dengan para hambanya. Paraingu yang berada di desa Patawang ini ketika pengambilan data memiliki sekitar delapan puluh lima orang keturunan bangsawan yang masih mempertahankan kedudukannya sebagai bangsawan yang asli dan dari tujuh paraingu dijelaskan bahwa ada terdapat sekitar seratus empat puluh dua orang ata (hamba) yang masih ada sampai sekarang dari jumlah tersebut yang masih tinggal dengan tuannya sekitar enam puluh enam orang sedangkan yang lainnya tinggal di uma wooka (rumah kebun), yaitu sekitar tujuh puluh enam orang. Dijelaskan juga bahwa menurut cerita leluhur, pada awalnya dulu semua hamba-hamba para bangsawan tinggal bersama tuannya di paraingu nya masing-masing, yaitu uma paraing/uma mbatang, tetapi seiring berjalannya waktu, jumlah hamba dalam paraingu itu juga bertambah banyak dikarenakan proses perkawinan yang terjadi.

Dalam hubungan maramba ata memiliki perbedaan dan, perbedaan yang paling terlihat dalam hubungan maramba dan ata ialah tingkat pendidikan yang ditempuh oleh kedua jenis golongan ini, dalam penelitian ini Samiyono melihat bahwa sebagian besar dari golongan bangsawan yang ada di desa Patawang sangat menikmati bangku pendidikan (sebagian besar lulusan SMA dan tidak sedikit juga yang sampai kepada Perguruaan Tinggi). Sebaliknya dari golongan hamba, hampir sebagian dari mereka tidak bersekolah, khususnya bagi mereka yang tinggal dengan tuannya di uma paraing. Diantara mereka, hanya lulusan SD dan tidak sedikit ditemukan golongan ini hanya menikmati bangku sekolah sampai kelas II atau III dan setelah itu mereka putus sekolah. Mereka tidak bersekolah bukan karena keinginan mereka, melainkan karena mengikuti perintah tuannya karena menurut tuannya ada pekerjaan yang lebih penting dan banyak dibandingkan pergi bersekolah. Jika dilihat dari aspek perkawinan, seorang maramba tidak diijinkan untuk menikahi seorang dari golongan ata, hal itu bukanlah sesuatu yang diharapkan.

Samiyono melakukan wawancara dengan seorang pemangku adat dan menurut pengakuannya perihal pernikahan maramba-ata yang tabu dalam masyarakat karena ketika seorang dari golongan maramba menikahi seorang dari golongan ata, hal itu akan berpengaruh pada derajat dan status dari golongan maramba tersebut, dan sudah tentu maramba tersebut akan dikucilkan oleh keluarganya. Menurut pandangan masyarakat Sumba, sebuah harga diri merupakan sesuatu yang sangat diperhatikan dan sangat penting. Dalam penelitian yang dilakukan golongan maramba yang ada di desa Patawang belum ada yang

\footnotetext{
${ }^{10}$ Jami dan Samiyono, Maramba dan Ata: Hubungan raja dan hamba di Desa Patawang - Sumba Timur, 41.
} 
menikah dengan golongan ata secara sah, tetapi banyak ditemukan di lapangan adalah golongan maramba yang hanya ingin melampiaskan hawa nafsunya kepada hambanya (pemuas ranjang) dan perlu untuk diketahui hal-hal seperti itu sudah menjadi rahasia umum di dalam masyarakat. Anak hasil dari kedua jenis golongan tersebut akan diangkat oleh tuannya menjadi anak dengan status yang berbeda dan anak ini akan disebut bangsawan kalawihi dan mereka diberi kesempatan untuk mengenyam pendidikan." 11

Dalam praktik maramba ata di Sumba dapat diperoleh dengan "sah" dengan beberapa cara salah satunya seperti pembayaran mahar, bahasa setempat untuk menyebut pembelian atau pembayaran mengenai fenomena itu adalah "belis", yaitu pembayaran maskawin tetapi tanpa ada mempelai yang melamar, tetapi pembelisan ini berlangsung persis dengan acara peminangan. Biasanya pembelisan dilakukan kepada seorang hamba (wanita). Hamba (wanita) yang telah selesai dengan pembelisan akan dibawah ke rumah "tuannya" dan dia akan melayani seumur hidupnya di sana. Biasanya wanita yang telah di belis menjadi hamba tidak dapat keluar dari rumah itu sekalipun dia akan atau sudah menikah, biasanya jika hamba perempuan itu ingin menikah maka mempelai pria yang ingin menikahi hamba wanita itu akan kawin masuk (dia akan menjadi hamba di rumah tuan istrinya). Hamba tersebut bukan hanya bekerja sebatas pekerjaan rumah tangga tetapi hamba juga terkadang dapat dipakai untuk melalui tuannya dalam urusan ranjang. Seorang hamba sepenuhnya menjadi tanggung jawab dari tuannya, dalam observasi langsung yang penulis lakukan pengakuan yang di dapat olehnya adalah kebiasaan ini lahir dari tradisi di Alkitab.

Di dalam Alkitab seorang budak merupakan aset ekonomi, harta milik yang legal dan tanggung jawab sepenuhnya dari pembelinya. ${ }^{12}$ Hal ini berarti pembeli yang menjadi tuan dari budak itu bertanggung jawab penuh atas hambanya baik secara lahir dan batin. Budak yang telah dibeli akan tinggal di rumah tuannya sampai akhir hidupnya hal ini berarti budak itu akan melahirkan dan membesarkan anak di rumah tuannya dan anak itu akan mempunyai status sebagai "anak dalam rumah". Sejarah, yang dicatatkan di dalam Alkitab yang mengisahkan tentang praktik perbudakan pada masanya, yaitu bangsa Israel yang di mana mereka diperbudak oleh Mesir dan telah diketahui bahwa peradaban terbesar terjadi di sana. Mesir terkenal dengan peradaban kuno dan beberapa monumen kuno termegah yang ada di dunia dan hal ini menjadikan Mesir diakui secara luas sebagai pusat budaya dan politikal utama di wilayah Arab dan Timur Tengah. Hal ini berhubungan dengan apa yang coba dijelaskan oleh filsafat Agama.

Filsafat agama adalah refleksi filosofis yang berbicara tentang hal-hal yang berkaitan dengan isu-isu agama dengan menggunakan metode filsafat secara sistematis dan menocaba untuk memeriksa nilai kebenaran, mitos, simbol, upacara yang terjadi yang berasal dari

${ }^{11}$ Jami dan Samiyono, Maramba dan Ata: Hubungan raja dan hamba di Desa Patawang - Sumba Timur, 61-62.

${ }^{12}$ Ryken Leland, James C. Wilhoit, dan Tremper Longman III, ed., Kamus Gambaran Alkitab (Surabaya: Momentum, 2011), 180. 
sejarah agama. ${ }^{13}$ Berangkat dari fenomena-fenomena yang terjadi tersebut, maka perlu untuk diketahui adalah fenomenologi mempelajari gejala-gejala sosial budaya dengan memulai dari hal-hal yang mendasari perilaku manusia, yakni kesadaran. Maka fenomenologi tidak mengajukan perumpamaan-perumpamaan atau model-model sebagaimana pendekatanpendekatan yang lain. ${ }^{14}$

\section{Metode}

\section{Jenis Penelitian}

Jenis penelitian yang digunakan oleh penulis dalam karya ilmiah ini adalah kualitatif. Lexy J. Moleong menagtakan bahwa penelitian kualitatif yang bermaksud untuk memahami fenomena tentang apa yang dialami oleh subjek penelitian misalnya perilaku, persepsi, tindakan, dll., secara holistik, dan dnehann cara deskripsi dalam bentuk kata-kata dan bahasa, pada suatu konteks khusus yang alamiah dan dengan memanfaatkan berbagai metode alamiah. ${ }^{15}$ Metode kualitatif pada prinsipnya ingin menerangkan, mendeskripsikan secara kristis suatu fenomena, suatu kejadian interaksi sosial dalam masyarakat untuk mencari dan menemukan makna dalam konteks yang sesungguhnya. ${ }^{16}$ Jenis penelitian kualitatif bersifat deskriptif pendekatan ini berupa penelitian lapangan dan juga penelitian kepustakaan. ${ }^{17}$ Menurut Bogdan dan Taylor (1955) penelitian kualitatif adalah prosedur penelitian yang menghasilkan data deskriptif berupa kata-kata tertulis atau lisan dari orang-orang dan perilaku yang dapat diamati. ${ }^{18}$ Dalam hal ini berartii penulis akan menggunakan metode penelitian kualitatif dalam mengumpulkan informasi-informasi yang dibutuhkan yang menyangkut karya ilmiah penulis. Menentukan populasi dan sampel merupakan hal terpenting dalam sebuah penelitian guna memberikan data-data yang akurat dan dapat dipertanggungjawabkan oleh setiap peneliti.

\section{Key Person}

Key person adalah metode pengumpulan data melalui wawancara mendalam. Key person adalah mereka yang dipilih secara khusus untuk menjelaskan mengenai aspek-aspek perbudakaan dalam suku Sumba. Penentuan jumlah key person tergantung pada kebutuhan dan pentingnya peran masing-masing key person. Yang menjadi key person yakni salah seorang gembala siding pada suatu gereja, seorang kepala dusun, seorang hamba yang juga pengerja pada suatu gereja, seorang bapak dari kalangan bangsawan, seorang kaum hamba di

\footnotetext{
${ }^{13}$ Mariasusai Dhavamony, Fenomenologi Agama (Yogyakarta: Kanisius, 1995), 23.

${ }^{14}$ Heddy Shri Ahimsa-Putra, "Fenomenologi Agama: Pendekatan Fenomenologi Untuk Memahami Agama,” Jurnal Penelitian Sosial Keagamaan 20. No. 2 (Desember 2012): 283, doi:10.21580/ws.20.2.200.

${ }^{15}$ Mamik, Metodologi Kualitatif (Jawa Timur: Zifatama Jawara, 2015), 4.

${ }^{16}$ A. Muri Yusuf, Metode Penelitian Kuantitatif, Kualitatif \& Penelitian Gabungan (Jakarta: Kencaana, 2017), 338.

${ }^{17}$ Ibid.

${ }^{18}$ I. Wayan Suwendra, Metodologi Penelitian Kualitatif dalam Ilmu Sosial, Pendidikan, Kebudayaan dan Keagamaan (Bali: Nilacakra, 2018), 4.
} 
lingkungan tersebut. Selain itu, wawancara akan dilakukan kepada beberapa warga yang tinggal disekitar tempat penelitian dan juga beberapa warga yang berjemaat pada gereja yang menjadi tempat penelitian.

\section{Teknik Pengumpulan Data}

Untuk memperoleh data yang dapat dipercayai dan dipertanggungjawabkan, maka penulis menggunakan beberapa teknik untuk mengumpulkan data, yaitu: 1) Teknik kepustakaan menurut Koentjaraningrat, teknik kepustakaan merupakan cara pengumpulan data dn informasi dengan bantuan bermacam-macam materi yang didapat di ruang perpustakaan, misalnya koran, dokumen, naskah, caatatan-catatan sejarah, dsb. Teknik kepustakaan ini dilakukan dengan menggali sebanyak mungkin informasi-informasi yang dibutuhkan untuk penelitian. 2) Observasi Langsung. Observasi langsung adalah kegiatan mengumpulkan data dengan cara terjun langung ke lapangan dengan melihat subjek yang diteliti. Hal ini berarti penulis akan terjun langsung ke lapangan untuk mengumpulkan informasi-informasi yang dibutuhkan dalam penulisan. 3) Wawancara. Wawancara adalah kegiatan Tanya jawab yang terjadi antara orang yang mencari informasi (pewawancara) dengan orang yang memberi informasi (narasumber dengan tujuan untuk mengumpulkan data atau memperoleh informasi. ${ }^{19}$ Metode wawancara ini akan digunakan oleh penulis di lapangan untuk mengumpulkan data-data bagi karya ilmiah. Wawancara ini melibatkan beberapa orang dengan topik perbudakan di Sumba Timur. Penulis akan memberikan beberapa pertanyaan kepada narasumber dan penulis akan mengumpulkannya.

\section{Teknik Analisis Data}

Patton mengatakan analisis data adalah proses mengatur urutan data, mengorganisasikan ke dalam suatu pola, kategori dan kesatuan uraian dasar. ${ }^{20}$ Teknik pengumpulan data yang digunakan penulis dalam penelitian ini adalah teknik wawancara. Wawancara merupakan bukti terhadap informasi data yang diperoleh sebelumnya. Tujuan dari analisa data adalah agar setiap data yang diperoleh dapat dikelolah dengan baik sehingga mudah dianalisa oleh penulis untuk diuji kebenarannya serta dapat dipertanggungjawabkan. Dari hasil pengumpulan data yang diperoleh melalui wawancara, penulis akan menganalisa data dengan cara kualitatif dan disajikan dalam bentuk deskripsi.

Pada penelitian kualitatif ini, teknik analisis yang digunakan mengacu kepada fenomenologi Husserl, dan berikut adalah analisis data tersebut: 1) Menentukan fenomena yang ingin diteliti dan peran peneliti dalam penelitian tersebut. Menentukan fenomena yang menjadi fokus penelitian memerlukan beberapa pertimbangan, antara lain keefektifan fenomenologi Husserl untuk menghasilkan pemahaman yang lebih baik tentang fenomena.

\footnotetext{
${ }^{19}$ Joko Untoro dan Tim Guru, Buku Pintar Pelajaran Ringkasan Materi Lengkap dan Kumpulan Rumus Lengkap (Jakarta: Wahyu Media, 2010.), 245.

${ }^{20}$ Sustiyo Wandi, Tri Nurharsono, dan Agus Raharjo, "Pembinaan Prestasi Ekstrakurikuler Olahraga di SMA Karangturi Kota Semarang,” Journal of Physical Education 2. No. 8 (2013): 527.
} 
Selanjutnya, peran peneliti juga harus jelas. 2) Pengumpulan data Proses pengumpulan data meliputi proses pemilihan partisipan atau sampel dan metode pengumpulan data. Pada umumnya, fenomenologi menggunakan teknik purposeful sampling, di mana setiap orang yang mempunyai pengalaman tentang fenomena yang sedang diteliti berhak untuk menjadi partisipan Teknik pengumpulan data yang sering digunakan adalah wawancara. Wawancara yang dilakukan dapat berbentuk wawancara terbuka atau semi-terstruktur. Proses wawancara direkam dan pada umumnya dilakukan lebih dari satu kali untuk melengkapi atau memvalidasi data yang diperlukan. 3) Perlakuan dan Analisis data Analisis data didahului dengan proses transkripsi hasil wawancara secara verbatim atau apa adanya. Setiap transkrip diberi identitas, diperiksa keakuratannya, dan dianalisis. 4) Studi literatur Setelah proses analisis data selesai maka peneliti melakukan studi literatur secara mendalam untuk mengetahui hubungan dan posisi hasil penelitian terhadap hasil-hasil penelitian yang telah ada. 5) Mempertahankan kebenaran hasil penelitian Seperti halnya penelitian kuantitatif, penelitian kualitatif juga menuntut adanya validitas dan reliabilitas. Dalam penelitian kualitatif pada umumnya validitas dan reliabilitas dikenal sebagai credibility, auditability, dan fittingness. 6) Pertimbangan etik yang harus diperhatikan meliputi pemberian informasi tentang sifat penelitian, keikutsertaan yang bersifat sukarela, ijin untuk merekam interview, kerahasiaan identitas partisipan baik pada rekaman, transkrip, maupun pada deskripsi lengkap.

\section{Hasil}

Secara sederhana praktik perbudakan terjadi karena beberapa faktor dan factor-faktor yang mempengaruhi adanya praktik itu antara lain; politik, ekonomi, dan budaya. Penulis akan memaparkan hasil penelitian lapangan di mana menggunakan penelitian kualitatif yang dapat dianalisis, yaitu untuk meninjau, menganalisis, dan mengetahui pandangan Gereja mengenai praktik perbudakan di Sumba Timur. Tujuan penelitian lapangan adalah mengetahui sejauh mana gereja menangani praktik perbudakan dalam suku Sumba.

\section{Faktor-faktor Penyebab Praktik Perbudakan "Maramba Ata”}

\section{Faktor Sosial}

Faktor sosial adalah salah satu cara untuk memperoleh budak dikarenakan pada zaman dahulu praktik pemerintahan Sumba adalah kerajaan dan dari faktor ini masih ada nilai-nilai yang masih ditemui saat ini, secara praktisi masih ada dan relevannya di dalam masyarakat.

\section{Tema 1: Perkawinan antar golongan}

Berdasarkan hasil wawancara peneliti, ditemukan bahwa pendapat masing-masing informan dari 7 informan memiliki pendapat yang sama seperti yang mereka paparkan bahwa pernikahan beda golongan sebenarnya sudah dianggap biasa oleh masyarakat pada zaman ini. 
Seperti apa yang coba dijelaskan oleh seorang hamba Tuhan, yaitu informan 2 yang mengatakan, "pernikahan beda golongan bukanlah sesuatu yang buruk." "1 Memang benar bahwa pada zaman dahulu praktik ini bukanlah sesuatu yang dianggap baik dan biasa saja dilihat dari budaya setempat, tetapi karena banyak aspek hingga praktik ini mulai dipandang biasa saja, salah satunya karena gereja ada untuk memberikan pemahaman-pemahaman bahwa di hadapan Tuhan semua derajat manusia itu sama.

\section{Tema 2: Kedudukan istri dalam keluarga}

Berdasarkan hasil wawancara dari 7 informan semua menyetujui bahwa istri bukanlah seorang hamba, mereka tidak menyetujui hanya karena istri melakukan pekerjaan tersebut dianggap sebagai hamba. Mereka melakukan tanggung jawab mereka, seperti yang dikatakan oleh informan 6, "kami tidak menganggap mereka sebagai hamba, tetapi itu adalah tugas mereka." 22 Tetapi, apa yang terjadi di lapangan sangatlah berbeda, memang benar pekerjaan di ladang diambil ahli oleh pria, tidak sedikit juga bahwa biasanya para istri akan membantu, tapi ketika peneliti berada di lapangan apa yang peneliti lihat adalah, pekerjaan di ladang bahkan dikerjakan oleh istri biasanya pekerjaan rumah akan dilakukan oleh istri juga dibantu dengan anak-anak mereka, atau anak sekolah yang tinggal bersama mereka. Apa yang dilakukan oleh kebanyakan suami? Mereka hanya bersantai-santai hingga siang hari dan lalu pada siang menjelang sore akan pergi ke area petarung ayam/judi (sambung ayam). Seperti apa yang peneliti lihat dan saksikan di lapangan adalah setiap masalah-masalah mengenai pernikahan/peran setiap anggota keluarga yang mulai dikomentari maka statement yang sudah tertanam oleh masyarkat adalah 'kan sudah dibelis' pernyataan itu yang peneliti dapat di sana, dan seperti apa yang disampaikan oleh informan 7, "apa gunanya jika dulu keluarga saya membelis dia pekerjaan rumah saja tidak bisa dikerjakan.",23

\section{Faktor Ekonomi}

Permasalahn bagi masyarakat saat ini, yaitu memenuhi kebutuhan finansial, bukan hanya kelas bawah pada kenyataannya hampir semua golongan masyarakat mempunyai permasalahan yang sama, tetapi hal yang disayangkan adalah bagi mereka yang berada di golongan kelas bawah. Hidup tanpa pendapatan yang pasti dapat mempengaruhi kehidupan masyarakat ekonomi kelas bawah. Salah satu cara untuk memenuhi kebutuhan tersebut adalah dengan cara menawarkan diri sebagai seorang 'hamba'. Pada zaman ini 'hamba' lebih dikenal dengan istilah 'pembantu' atau 'asisten rumah tangga", mungkin secara teori kedua hal ini berbeda tetapi secara praktiknya mereka melakukan hal-hal yang sama.

\footnotetext{
${ }^{21}$ Andung, Wawancara Oleh Penulis, 6 Juli 2020.

${ }^{22}$ Emba, Wawancara Oleh Penulis.

${ }^{23}$ Djuanda, Wawancara Oleh Penulis.
} 


\section{Tema 3 dan 4: Human Trafficking}

Berdasarkan hasil wawancara 7 informan menjawab hal yang hampir sama, yaitu menurut mereka sebenarnya seorang yang menjadi hamba memang adalah seorang yang mempunyai kedudukan atau status yang memang adalah hamba, mengenai masalah perekonomian memang menjadi masalah juga tetapi bukan itu menjadi hal utama mereka menjadi hamba. Seperti apa yang coba disampaikan oleh informan 4, "semua orang mempunyai kebutuhan pribadi, tetapi siapa yang mau memperhatikan mereka?" 24 Maksudnya adalah seperti apa yang disampaikan informan 6, yaitu "orang yang bekerja yang akan diberi makan." 25 Jadi, menurut informan 5 sebaiknya adalah, "mereka butuh makan, apakah kami tidak bisa menyuruh mereka?"26

Ketika peneliti berada di lapangan, kenyataan yang peneliti lihat adalah banyak anakanak dari daerah tersebut yang pergi keluar untuk bekerja mencari nafkah, yaitu dengan menjadi TKI/TKW, dan biasanya negara Malaysia yang dituju untuk bekerja hal ini peneliti dengar melalui kesaksian para kerabat mereka di sana ketika peneliti berada di lapangan. Masalah tidak dapat memenuhi kebutuhan rumah tangga menyebabkan mereka dengan terpaksa melakukan hal tersebut.

\section{Faktor Budaya}

Kebudayaan mencakup aspek kepercayaan dan kebiasaan yang dilakukan yang akhirnya menjadi tradisi di daerah tersebut. Pada zaman dahulu para nenek moyang yang tiba di Sumba datang bersama dengan hamba mereka, yang disebut sebagai hamba pusaka. Ketika tiba di Sumba para nenek moyang mengambil hamba lagi dari penduduk pribumi.

\section{Tema 5: Tradisi nenek moyang}

Berdasarkan hasil wawancara tersebut menurut para informan budaya dan gereja bisa berjalan bersama karena budaya ada lebih dulu tetapi keselamatan ada di dalam Kristus. Budaya bisa dikikis di mana praktiknya tetap ada tetapi maknanya yang di rubah. Pada zaman dahulu di Sumba Timur, para marapu yang datang ke Sumba datang memboyong isi rumahnya termsauk hamba-hambanya. Hamba-hamba ini disebut sebagai ata ndai atau hamba pusaka yang adalah hamba yang datang bersama tuannya.

\section{Pembahasan}

\section{Gereja dan Kebudayaan}

Secara etimologi gereja berasal dari bahasa Portugis, yaitu 'igreja' dan dalam Bahasa inggris adalah 'church'. Gereja memiliki dua pengertian, yang pertama kepada seorang

\footnotetext{
${ }^{24}$ Meha, Wawancara Oleh Penulis, 4 Juli 2020.

${ }^{25}$ Emba, Wawancara Oleh Penulis.

${ }^{26}$ Kaley, Wawancara Oleh Penulis.
} 
pribadi yang percaya dan menunjuk kepada suatu tempat di mana orang-orang percaya tersebut berkumpul. Kebudayaan mempengaruhi kehidupan seseorang.

Kebudayaan merupakan keseluruhan yang kompleks yang mencakup pengetahuan, kepercayaan, kesenian, moral, hukum adat-istiadat, kemampuan dan kebiasaan lainnya yang diperoleh manusia sebagai anggota masyarakat. Perlu diketahui bahwa manusia tidak hidup secara bebas di dalam dunia ini karena mereka hidup dibawah aturan-aturan, hukum-hukum yang berlaku turun-temurun. Suatu praktik dibentuk oleh situasi yang terjadi, dan praktik perhambaan terjadi karena situasi yang ada maksudnya adalah ada peran budaya yang melahirkan praktik perhambaan yaitu melalui pelapisan sosial.

Sumba merupakan suatu daerah yang serupa dengan kerajaan besar yang di dalamnya terdapat golongan-golongan masyarakat. Masyarakat Sumba pada umumnya dibagi menjadi tiga golongan, yaitu golongan maramba (bangsawan), golongan biasa, dan golongan ata (hamba), karena peran budaya inilah melahirkan praktik perhambaan melalui golongangolongan.

Bagi orang Sumba ada tiga hal yang berkaitan dengan identitas budaya mereka, yaitu tatanan berdasarkan keyakinan beragama (Marapu), tatanan berdasarkan tempat (paraingu), dan tatanan berdasarkan ikatan kekeluargaan (kabihu). Dari ketiga tatanan tersebur, tatanan berdasarkan agama Mагарu itulah menjadi penanda identitas terpenting. Berangkat dari hal inilah banyak tardisi-tradisi yang terus dilestarikan hingga saat ini, bahkan jika seseorang yang ingin menjadi Kristen sangatlah sulit karena hukum-hukum yang berlaku tersebut. Hal ini yang menjadi tugas gereja.

\section{Kesimpulan}

Berdasarkan uraian dalam skripsis ini penulis dapat memberikan kesimpulan sehubungan dengan penejelasan yang telah dipaparkan di bab-bab sebelumnya. Dari hasil analisis data wawancara yang penulis lakukan dalam penelitian maka dapat disimpulkan bahwa: Pertama, perbudakan merupakan praktik yang lahir dari tradisi dan budaya setempat yang dibawah oleh para marapu, tetapi gereja berusaha untuk meninggalkan praktik tersebut perlahan-lahan atas pelayanan dan juga perhatian yang diberikan oleh gereja terus-menerus. Jemaat dan juga masyarakat harus memahami budaya bukan dari perspektif sebelum kenal Yesus Kristus, tetapi melihat budaya itu dari pandangan setelah menjadi seorang percaya seperti yang Rasul Paulus katakan dalam Galatia 3:28 "Dalam hal ini tidak ada orang Yahudi atau orang Yunani, tidak ada hamba atau orang merdeka, tidak ada laki-laki atau perempuan, karena kamu semua adalah satu di dalam Kristus Yesus.” Hukum Taurat itu membedakan orang Yahudi dengan orang Yunani dengan cara memberi orang Yahudi keunggulan dalam banyak hal. Hal itu juga membuat perbedaan di antara hamba atau orang merdeka, tuan dengan hamba, dan laki-laki atau perempuan, mengingat bahwa orang laki-laki harus disunat. Namun, sekarang tidak begitu halnya. Mereka semua setara, karena semua adalah satu di dalam Kristus Yesus. Sama seperti seseorang tidak diterima berdasarkan keunggulan- 
keunggulan kebangsaannya ataupun pribadinya yang mungkin dimilikinya melebihi orang lain, demikian juga orang lain tidak akan ditolak karena tidak memiliki segala keunggulan tersebut. Sebaliknya, siapa saja yang benar-benar percaya kepada Kristus, tidak peduli dari suku bangsa, jenis kelamin, ataupun keadaan apa pun, akan diterima oleh-Nya dan menjadi anak-anak Allah melalui iman kepada-Nya.

Kedua, gereja memberikan masukan-masukan walaupun secara tindakan masih belum bisa dikatakan maksimal tetapi gereja sedang berusaha untuk mensejahterakan jemaat dan masyarakat. Maka itu penting untuk gereja mempelajari kontekstual agar gereja dapat memilah mana tardisi-tardisi yang dapat dikontekstualkan seperti dalam kebudayaan Sumba, yaitu agar budaya dan agama bisa berjalan bersama tanpa harus bertolak belakang. Jika ada pengajaran yang tidak sesuai dengan Alkitabiah gereja, jemaat harus berani untuk mengikisnya. Jika itu mengenai perekonomian, gereja harus dan akan berupaya untuk membantu mensejahterakan jemaat dengan berkerja sama bersama pemerintah setempat agar praktik-praktik tersebut perlahan-lahan dihilangkan.

\section{Rujukan}

Ahimsa-Putra, Heddy Shri. "Fenomenologi Agama: Pendekatan Fenomenologi Untuk

Memahami Agama." Walisongo: Jurnal Penelitian Sosial Keagamaan 20, no. 2 (15

Desember 2012): 271-304. doi:10.21580/ws.20.2.200.

Andung, Yohanis H. Remi. Wawancara oleh Penulis, 6 Juli 2020.

Bales, Kevin. "Expendable People: Slavery in the Age of Globalization." Journal of

International Affairs 53, no. 2, (2000): 461-84.

Dhavamony, Mariasusai. Fenomenologi Agama. Kanisius, 1995.

Djuanda, Umbu. Wawancara oleh Penulis, 30 Juni 2020.

Emba, Yusak Pundar. Wawancara oleh Penulis, 30 Juni 2020.

Ivan Th.J Weismann. "Naturalisasi Perbudakan Sebagai Suatu Keadilan.” Jurnal Jaffray, no.

1 (2015): 29.

Jami, Dorkas, dan David Samiyono. Maramba dan Ata: Hubungan raja dan hamba di Desa

Patawang - Sumba Timur. Salatiga: Fakultas Teologi Universitas Kristen Satya

Wacana Press, 2009.

Kaley, Martinus. Wawancara oleh Penulis, 30 Juni 2020.

Kompasiana.com. "24 Rekor Dunia yang Dipegang Indonesia.” KOMPASIANA. Diakses 21

Februari 2020.

https://www.kompasiana.com/misdianto/54ff581aa333112b4a50ff8e/24-rekor-duniayang-dipegang-indonesia.

Leland, Ryken, James C. Wilhoit, dan Tremper Longman III, ed. Kamus Gambaran Alkitab. Surabaya: Momentum, 2011.

Mamik. Metodologi Kualitatif. Jawa Timur: Zifatama Jawara, 2015.

Meha, Apris Maramba. Wawancara oleh Penulis, 4 Juli 2020. 
Nasution, Ahmad Sayuti Anshari. "Perbudakan dalam Hukum Islam." AHKAM : Jurnal Ilmu Syariah 15, no. 1 (21 Februari 2019). doi:10.15408/ajis.v15i1.2852.

Pringgodigdo, A. G. Ensiklopedi Umum. Yogyakarta: Kanisius, 1991.

Shils, Edward, dan dkk. Elit Dalam Perspektif Sejarah. Jakarta: Lembaga Penelitian, Pendidikan dan Penerangan Ekonomi, 1981.

Suwendra, I. Wayan. Metodologi Penelitian Kualitatif dalam Ilmu Sosial, Pendidikan, Kebudayaan dan Keagamaan. Bali: Nilacakra, 2018.

Untoro, Joko. Buku Pintar Pelajaran Ringkasan Materi Lengkap dan Kumpulan Rumus Lengkap. Jakarta: WahyuMedia, 2010.

Wandi, Sustiyo, Tri Nurharsono, dan Agus Raharjo. "PEMBINAAN PRESTASI EKSTRAKURIKULER OLAHRAGA DI SMA KARANGTURI KOTA SEMARANG." Journal of Physical Education 2, no. 8 (2013): 12.

Yasa, Putu Pertama, Ketut Sidang Partayasa, dan I Nyoman Linggih. "Tradisi 'Nyakan Diwang" Untuk Mempererat Tali Persaudaraan." Http://jayapanguspress.penerbit.org/index.php/PN/article/view/341/331, 19 April 2020 .

Yusuf, A. Muri. Metode Penelitian Kuantitatif, Kualitatif \& Penelitian Gabungan. Jakarta: Kencana, 2017. 